Original Research Paper

\title{
Adsorption of Nickel and Zinc by Residual Soils
}

\author{
Nur 'Aishah Zarime, W.Y. Wan Zuhairi and Sivarama Krishna \\ Geology Programme, School of Environmental Sciences and Natural Resources, Faculty of Science and Technology, Universiti \\ Kebangsaan Malaysia, 43600 Bangi, Selangor, Malaysia
}

Article history

Received 23-04-2014

Revised 26-06-2014

Accepted 27-11-2014

Corresponding Author: Nur 'Aishah Zarime, Geology Programme, School of Environmental Sciences and Natural Resources, Faculty of Science and Technology, Universiti Kebangsaan Malaysia, 43600 Bangi, Selangor, Malaysia Email: drwzwy@gmail.com

\begin{abstract}
Soil has long been utilized as low cost liner material to prevent contamination from leachate to groundwater media. To find a suitable soil material for this purpose is a great challenge. This study describes the potential use of residual soil to functions as engineered clay liner for waste disposal landfill in Malaysia. Three types of residual soils were investigated namely marine clays (SBMC1, SBMC2), Residual Granites (BGR, KGR) and residual meta-sediments (BBMS1, BBMS2 and PMS). Physical and chemical tests were applied for both granitic soils to determine the physical and chemical properties of soil materials. Physical and chemical tests involved grain size distribution, Atterberg limits, compaction, $\mathrm{pH}$, organic content, specific gravity, Cation Exchange Capacity (CEC) and Specific Surface Area (SSA) as well as Batch Equilibrium Test for adsorption of heavy metals. The best potential soil materials for clay liner is the materials that have high $\mathrm{pH}$ value, high organic matter, high liquid and plastics limits, high CEC and SSA values. The best material also highly dominated with clay (in this case PKMC, SBMC1 and SBMC 2). Result show the range of $\mathrm{pH}$ values are from 6.95-8.36, range of organic content are from $4.35-6.41 \%$, the specific conductivity values range from 2.13-2.34 and for liquid limit and plastic limit range are from $56.40-84$ and $26.86-59.35 \%$ respectively; which is high to very high plasticity. Residual soils as low-cost adsorbent materials were also used for removal of Nickel (Ni) and Zinc ( $\mathrm{Zn})$ from aqueous solutions. Batch test was used and the effect of heavy metal concentration was studied. Results were analyzed using adsorption isotherm models (i.e., Linear, Langmuir and Freundlich). Based on the correlation coefficient ( $\mathrm{r} 2$ values), most of residual soils fitted nicely to Linear, Langmuir and Freundlich models. For Ni, most soils fitted to Langmuir models except for meta-sediment while for $\mathrm{Zn}$ fitted to Linear model. Marine clay has the highest adsorption coefficient ranged between $\mathrm{KL}=0.2380-0.9655$ $\mathrm{L} \mathrm{kg}^{-1}$ followed by granite and meta-sediment $\mathrm{KL}=0.0031-0.0168 \mathrm{~L} \mathrm{~kg}^{-1}$ and $\mathrm{KL}=0.0016-0.0075 \mathrm{~L} \mathrm{~kg}^{-1}$ respectively. While for $\mathrm{Zn}$, marine clay also has the best adsorption coefficient ranged between $\mathrm{Kd}=0.0453-0.1249 \mathrm{~L} \mathrm{~kg}^{-1}$, followed by granite and meta-sediment ranged between $\mathrm{Kd}=0.0027-0.0028 \mathrm{~L}$ $\mathrm{kg}^{-1}$ and $\mathrm{Kd}=0.0012-0.0016 \mathrm{~L} \mathrm{~kg}^{-1}$. The selectivity sequence $\mathrm{KL}$ for $\mathrm{Ni}$ is SBMC2 $>$ SBMC1 $>$ PKMC $>$ BGR $>$ PMS $>$ KGR $>$ BBMS2 $>$ BBMS1 while for $\mathrm{Zn}$, the selectivity sequence of $\mathrm{Kd}$ is $\mathrm{SBMC2}>\mathrm{SBMC1}>\mathrm{PKMC}>$ BBMS1> BBMS2 $>$ PMS $>$ BGR $>$ KGR. The study concludes that marine clay is the best material for landfill clay liner due to suitable physical-chemical characteristics and also appeared to be the best natural adsorbent of $\mathrm{Ni}$ and $\mathrm{Zn}$ of metal concentration in solution.
\end{abstract}

Keywords: Residual Soils, Heavy Metals, Physical-Chemicals Properties, Adsorption Isotherm

\section{Introduction}

Solid wastes are part of environmental pollution's contributor. Landfill; which is an engineered waste disposal site with specific pollution control is designed to minimize pollution. However, Malaysia's landfills are still using the oldest and very common way of disposing which is open dumping due to the increase of pollutions. 
Its occur when solid phase (waste), liquid phase (leachate) and gas phase form due to biological, physical, chemical and other influent factors of waste (Sabahi et al., 2009). Leachate can percolate through the base of landfill, enter the groundwater systems and change the quality of groundwater (Taha et al., 2011). Engineered clay liners are utilized to Malaysia sanitary landfill by using the compacted clay to prevent the seepage and remove heavy metals commonly found in landfill leachate. Many metals ions are essentials as trace elements but in higher concentration it's become toxic. Heavy metals are difficult to remove from environment unlike other pollutant that chemically or biologically degraded (Komy et al., 2013). Therefore, conventional clay liners are design with the focus on minimizes the permeation of leachate through liner. Residual soils are chosen to be clay liner as abundance and availability of this residual soil will make them economically feasible (Rosli et al., 2008). Soil structures and the various size fractions have their own ability to absorb and transfer to the environment (Huang et al., 2014). The capacity of natural soil to adsorb heavy metals has been study and published by many researchers (Antoniadis et al., 2007; Zuhairi et al., 2008). Mobility of heavy metals in soils can be describe by distribution coefficient $(\mathrm{Kd})$ where $\mathrm{Kd}$ is one of the input parameters in contaminant transport modeling to model the contaminant flow in groundwater (Zuhairi and Samsudin, 2007). $\mathrm{Kd}$ parameter shows the absorption or attenuation of contaminant. The objectives of this study are to investigate the attenuation capability of natural geologic material based on chemical-physical and adsorption properties and proposed the best materials that function as engineered clay liner for landfill application.

\section{Material and Methods}

\section{Material}

In the present study, eight samples were collected from Selangor area in Malaysia and they consist of three types of residual soils which were; granitic residual soils from Broga (BGR) and Kajang (KGR), meta-sediment residual soils from Puchong (PMS) and two samples from Bukit Badong (BBMS 1 and BBMS 2) and marine clay from Port Klang (PKMC) and two samples from Sungai Besar (SBMC 1 and SBMC 2). All samples were air-dried and sieved into $0.125 \mathrm{~mm}$ and $63 \mu \mathrm{m}$ for soil tested.

\section{Physical-Chemical Characteristics}

Physical-chemical tests were conducted according to British Standard Method, BS1377 (1990) and Geotechnical Research Centre, Montreal, Canada (1985). Physical properties test consist of particle size distribution, Atterberg Limits, specific gravity and compaction while chemical properties test consist of soil $\mathrm{pH}$, organic matter, Specific Surface Area (SSA) and Cation Exchange Capacity (CEC).

\section{Sorption Test}

Samples were tested using Batch equilibrium test where this test provides a quick method of estimating the contaminant retention capacity of any liner material (Zuhairi and Samsudin, 2007). This test used to study the behavior of natural soil (adsorbent) through a different initial concentration factor.

\section{Preparation}

After collecting soil samples, samples were air-dried and passed through $63 \mu \mathrm{m}$ sieve. To prepare the Ni and $\mathrm{Zn}$ metal, stock solutions were made using their nitrates and were further diluted with 10 different concentration 20 , $40,60,80,100,150,200,250,300$ and $400 \mathrm{mg} \mathrm{L}^{-1}$ under room temperature and controlled with $\mathrm{pH} 5-6$ by adding $\mathrm{HNO} 3$ and $\mathrm{NaOH}$. Nitrate salts were chosen because nitrate has poor ability to complex with metallic cations (Zuhairi et al., 2008). To perform this test, $4 \mathrm{~g}$ of soil sample (adsorbent) with $40 \mathrm{~mL}$ of metal aqueous solutions (1:10 ratio soil/solution) were added in centrifuge tubes. Samples were shaken 100 RPM under room temperature $\left(27 \pm 1^{\circ} \mathrm{C}\right)$ for $24 \mathrm{~h}$ for attained the equilibrium. After shaking, samples were centrifuged at 1500 RPM for 10 minutes and were filtered using $45 \mu \mathrm{m}$ nitrocellulose membranes. The $\mathrm{pH}$ of this solution also measured using pH meter (Hanna Instrument 2211). Solutions were analyzed using Couple Plasma Mass Spectroscopy (Perkin Elmer Model OPTIMA 3000 with auto sampler).

\section{Data Evaluation}

Adsorption isotherms are mathematical models where they describe the distribution of adsorbate among liquid and solid phases, based on assumptions that are related to the heterogeneity, homogeneity of solid surface, the type of coverage and the possibility of interaction between the adsorbate species (Babazadeh et al., 2011). The equilibrium adsorption isotherm is importance in the design of adsorption system (Parida et al., 2012).

\section{Adsorption Isotherm}

Adsorption data were analyzed using Linear, Langmuir and Freundlich isotherm models. The concentration of heavy metals adsorbed by soils, qe can be calculated by using following formula Equation 1:

$$
q_{e}=\frac{\left(C_{o}-C_{f}\right) V}{W}
$$

Where:

$C o$ and $C f=$ Initial concentration and equilibrium concentration of metal solution respectively $(\mathrm{mg} / \mathrm{L})$

$V \quad=$ Volume of solution added $(\mathrm{mL})$

$W \quad=$ Mass of air-dried soil $(\mathrm{g})$ 
Langmuir isotherm model is valid for mono-layer adsorption onto a surface with a finite number of identical sites and also considered several assumptions like the localized adsorption, similar energies on the surface of active sites where there is no interaction between adsorbed molecules and the surface of heterogeneous catalytic reactions (Parida et al., 2012; Tang et al., 2012). Langmuir models represented in following equations (Galedar and Younesi, 2013) Equation 2:

$q_{e}=\frac{K_{L} \cdot A_{m} C_{e}}{1+K_{L} \cdot C_{e}}$

The linear equation for Langmuir model given as below Equation 3:

$\mathrm{Ce} / q_{e}=1 / K_{L} \cdot A_{m}+\mathrm{Ce} / A_{m}$

Where:

$\mathrm{KL}=$ Langmuir binding constant $(\mathrm{L} / \mathrm{mg})$

$\mathrm{Am}=$ Saturated adsorption amount of metal ions $(\mathrm{mg} / \mathrm{g})$

$\mathrm{Ce}=$ Equilibrium concentration of metal ions $(\mathrm{mg} / \mathrm{L})$

Freundlich isotherm model is an empirical equation assuming that the adsorption process takes place on heterogeneous surface (Ruffino and Zanetti, 2009; Li et al., 2010; Sivarama Krishna et al., 2012; Tang et al., 2012). It also used to describe the adsorption of organic and inorganic components in solution (Parida et al., 2012) and represent an ideal situation, which does not include the possible saturation of the sorption sites (Sastre et al., 2007). The non-linear Equation 4 and linear Equation 5 for Freundlich models shows as below:

$q_{e}=K_{F} C_{e}^{1 / n}$

$\log q_{e}=\log K_{F}+(1 / n) \log C_{e}$

Where:

$\mathrm{KF}=$ Freundlich sorption coefficient
$1 / \mathrm{n}=$ Freundlich sorption exponent

$\mathrm{Ce}=$ The metal concentration in final contact concentration $(\mathrm{mg} / \mathrm{L})$

\section{Results}

\section{Soil Characterization}

The characteristics of each soil are tabulated in Table 1 and 2. Based on particle size distribution granitic residual soils have high percentage of sand ranged from $46-63 \%$, followed by meta-sediment residual soil which have ranged between $5-46 \%$ of sand while marine clay has the least of sand percentage ranged between $1-46 \%$.

Meta-sediment has the highest percentage of clay and plasticity index compared to marine clay ranged from $12-39$ and $32.448-42.90 \%$ respectively. Specific gravity also will confirm the types of grain sizes. Specific gravity result shows granitic soils give high values ranged from 2.45-2.66 followed by metasediment (2.32-2.67) and marine clay (2.13-2.34). Table 2 also shows $\mathrm{pH}$ and organic matter for each soil. The selective sequence from highest $\mathrm{pH}$ is PKMC $>$ SBMC $2>$ SBMC1 $>$ B GR $>$ KGR $>$ BBMS $2>$ BBMS $1>$ PM $\mathrm{S}$ where marine clay has highest $\mathrm{pH}$ values ranging from 6.95-8.36, followed by granitic soils ( $\mathrm{pH} 5.32-5.85)$ and meta-sediment soils ( $\mathrm{pH} 4.21-5.46$ ). Marine clay has the highest organic matter from $4.35-6.41 \%$, specific surface area (49.18-77.26\%) and cation exchange capacity (75.4$115.06 \mathrm{meq} / 100 \mathrm{~g})$.

Heavy metals adsorption capacities can be expressed in relationship between distribution coefficients, metal removed from solution per gram of the soil samples $(\mathrm{mg} / \mathrm{g})$ and the equilibrium of metals concentration in solutions $(\mathrm{mg} / \mathrm{L})$. These sorption isotherms provide the sorption behavior of soil suspension when they are at equilibrium with metal solutions (Wang and Nan, 2009). Table 3 and 4 show the summary of three main isotherm parameters that have been applied for $\mathrm{Ni}$ and $\mathrm{Zn}$ adsorption.

Table 1. Physical characteristics of adsorbent/residual soils

\begin{tabular}{|c|c|c|c|c|c|c|c|c|}
\hline Physical characteristics & BGR & KGR & PMS & BBMS 1 & BBMS 2 & PKMC & SBMC1 & SBMC2 \\
\hline \multicolumn{9}{|l|}{ Particle size distribution: } \\
\hline Sand (\%) & $54-63$ & $46-54$ & $40-46$ & $10-22$ & $5-13$ & $19-46$ & $1-8$ & $7-16$ \\
\hline Silt (\%) & $32-42$ & $41-50$ & $21-32$ & $62-72$ & $75-79$ & $46-67$ & $73-87$ & $66-76$ \\
\hline Clay (\%) & $1-6$ & $2-6$ & $25-39$ & $14-22$ & $12-16$ & $8-20$ & $12-19$ & $15-22$ \\
\hline \multicolumn{9}{|l|}{ Atterberg Limit: } \\
\hline Plastic Limit (\%) & $38.01-38.61$ & $35.03-36.67$ & $35.31-37.12$ & $52.98-59.68$ & $46.10-52.41$ & $26.86-31.00$ & $49.18-59.35$ & $46.09-49.16$ \\
\hline Liquid Limit (\%) & $48.50-50.00$ & $50.60-51.60$ & $65.00-69.60$ & $91.60-94.20$ & $84.50-89.00$ & $56.40-59.40$ & $79.50-84.00$ & $73.50-79.00$ \\
\hline Plasticity Index (\%) & $9.90-11.99$ & $14.63-16.27$ & $29.69-32.48$ & $34.12-40.82$ & $33.98-42.90$ & $28.00-30.11$ & $20.15-34.22$ & $24.34-30.91$ \\
\hline Specific Gravity & $2.50-2.59$ & $2.45-2.66$ & $2.63-2.67$ & $2.32-2.50$ & $2.37-2.48$ & $2.13-2.34$ & $2.14-2.29$ & $2.23-2.34$ \\
\hline Max Dry Density $\left(\mathrm{g} / \mathrm{cm}^{3}\right)$ & 1.75 & 1.71 & 1.42 & 1.37 & 1.50 & 1.63 & 1.37 & 1.39 \\
\hline Chemical characteristics & BGR & KGR & PMS & BBMS 1 & BBMS 2 & PKMC & SBMC1 & SBMC2 \\
\hline$\overline{\mathrm{pH}}$ & $5.35-5.85$ & $5.32-5.54$ & $4.21-4.38$ & $4.80-5.46$ & $4.54-4.92$ & $7.94-8.36$ & $6.95-7.42$ & $7.50-7.67$ \\
\hline Organic Matter (\%) & $0.22-0.34$ & $0.39-0.50$ & $0.45-0.54$ & $1.42-2.07$ & $0.84-1.23$ & $4.35-5.14$ & $5.31-6.06$ & $5.08-6.41$ \\
\hline $\mathrm{SSA}\left(\mathrm{m}^{2} / \mathrm{g}\right)$ & $17.96-21.93$ & $25.76-26.83$ & $32.53-36.81$ & $30.74-39.35$ & $35.59-40.13$ & $49.18-49.99$ & $60.28-62.38$ & $67.09-77.26$ \\
\hline $\mathrm{CEC}(\mathrm{meq} / 100 \mathrm{~g})$ & $0.79-1.35$ & $1.31-1.35$ & $0.55-0.96$ & $1.64-1.93$ & $2.81-3.07$ & $113.87-115.06$ & $91.25-92.32$ & $75.40-77.90$ \\
\hline
\end{tabular}

SSA: Specific surface area; CEC: Cation exchange capacity 
Table 3. Adsorption isotherm's result on Nickel (Ni)

\begin{tabular}{|c|c|c|c|c|c|c|c|c|c|}
\hline \multirow[b]{2}{*}{ Metals } & \multirow[b]{2}{*}{ Soils } & \multicolumn{2}{|c|}{ Linear equation } & \multicolumn{3}{|c|}{ Langmuir equation } & \multicolumn{3}{|c|}{ Freundlich equation } \\
\hline & & $\mathrm{K}_{\mathrm{d}}$ & $\mathrm{R}^{2}$ & $\mathrm{~K}_{\mathrm{L}}$ & $A_{m}$ & $\mathrm{R}^{2}$ & $\mathrm{~K}_{\mathrm{F}}$ & $\mathrm{n}$ & $\mathrm{R}^{2}$ \\
\hline \multirow[t]{8}{*}{$\mathrm{Ni}$} & BGR & 0.0049 & 0.4324 & 0.0168 & 0.3146 & 0.8847 & 0.7791 & 4.2827 & 0.7087 \\
\hline & KGR & 0.0021 & 0.3452 & 0.0031 & 0.4304 & 0.9803 & 0.6957 & 4.7170 & 0.9684 \\
\hline & PMS & 0.0047 & 0.9397 & 0.0075 & 0.3077 & 0.8265 & 0.6295 & 3.7397 & 0.7916 \\
\hline & BBMS1 & 0.0017 & 0.7252 & 0.0012 & 0.1875 & 0.6705 & 0.6449 & 5.2301 & 0.5536 \\
\hline & BBMS2 & 0.0015 & 0.6808 & 0.0016 & 0.5991 & 0.4667 & 0.4069 & 3.1706 & 0.8217 \\
\hline & PKMC & 0.0269 & 0.5323 & 0.2380 & 1.4562 & 0.9967 & 0.4733 & 0.7508 & 0.9727 \\
\hline & SBMC1 & 0.0667 & 0.5750 & 0.4471 & 1.8861 & 0.9962 & 0.5555 & 0.6063 & 0.9922 \\
\hline & SBMC2 & 0.1436 & 0.5230 & 0.9655 & 1.9406 & 0.9283 & 1.3161 & 0.5424 & 0.9579 \\
\hline
\end{tabular}

Table 4. Adsorption isotherm's result on Zinc (Zn)

\begin{tabular}{|c|c|c|c|c|c|c|c|c|c|}
\hline \multirow[b]{2}{*}{ Metals } & \multirow[b]{2}{*}{ Soils } & \multicolumn{2}{|c|}{ Linear equation } & \multicolumn{3}{|c|}{ Langmuir equation } & \multicolumn{3}{|c|}{ Freundlich equation } \\
\hline & & $\mathrm{K}_{\mathrm{d}}$ & $\mathrm{R}^{2}$ & $\mathrm{~K}_{\mathrm{L}}$ & $A_{m}$ & $\mathrm{R}^{2}$ & $\mathrm{~K}_{\mathrm{F}}$ & $\mathrm{n}$ & $\mathrm{R}^{2}$ \\
\hline \multirow[t]{8}{*}{$\mathrm{Zn}$} & BGR & 0.0016 & 0.8270 & 0.0059 & 0.6507 & 0.7056 & 27.4789 & 1.9912 & 0.7899 \\
\hline & KGR & 0.0012 & 0.3160 & 0.0025 & 0.2248 & 0.8087 & 9.5521 & 1.1818 & 0.9251 \\
\hline & PMS & 0.0027 & 0.8539 & 0.0056 & 0.5715 & 0.9077 & 28.3270 & 2.0153 & 0.9038 \\
\hline & BBMS1 & 0.0028 & 0.8310 & 0.0031 & 1.1892 & 0.2387 & 158.7084 & 4.0633 & 0.4189 \\
\hline & BBMS2 & 0.0028 & 0.7598 & 0.0027 & 0.4398 & 0.6498 & 17.6116 & 1.4486 & 0.9054 \\
\hline & PKMC & 0.0453 & 0.8295 & 0.2116 & 2.8265 & 0.1450 & 5.0957 & 2.2153 & 0.3884 \\
\hline & SBMC1 & 0.0711 & 0.8317 & 0.6128 & 4.4964 & 0.5107 & 4.7984 & 2.8345 & 0.3967 \\
\hline & SBMC2 & 0.1249 & 0.8133 & 0.6899 & 1.8646 & 0.8030 & 2.3529 & 1.8748 & 0.6699 \\
\hline
\end{tabular}

Higher R2 indicates good agreements with that isotherm. For $\mathrm{Ni}$, the experimental results it fitted to Langmuir and Freundlich isotherms model (R2>0.7) except for meta-sediment while for $\mathrm{Zn}$, most soils fitted to Linear equation except for granite residual soil. Correlation between Langmuir and Freundlich models gives better explanations on the influence of soil characteristics (Sastre et al., 2007). This is why authors attached the $\mathrm{pH}$ value of solutions after adsorption test. The $\mathrm{pH}$ of initial concentration is controlled at $\mathrm{pH}$ 5-6.

\section{Discussion}

Based on physical-chemical characteristics of residual soils, grain size plays important role in adsorption capacity. Granitic residual soil have highest percentage of sand where coarse-grained soils exhibit lower tendency for adsorption of heavy metal compared to fine-grained soil (Liew and Zuhairi, 2003). Metasediment also has the highest percentage of clay and plasticity index which indicates higher adsorption capability compared to marine clay (Zulfahmi et al., 2011). However, marine clay has the smallest value of specific gravity (1.37-1.39\%) where this would confirm that marine clay have higher fine particle (Chalermyanont et al., 2009). Fine-grained soils (i.e.,; PKMC, SBMC1 and SBMC2) have a large surface activity and large surface area such as clay minerals, humid acids and others which enhance adsorption capacity (Liew and Zuhairi, 2003). The surface area of clay will increase the contact area and facilitate adsorption of positively charged ions. So, clay easily accommodate heavy metals on its active sites through ion exchange and complexion (Lukman et al., 2013). High SSA also allows strong physical and chemical interactions with fluids and dissolved species, which subjected to electrostatic attraction, sorption or specific cation exchange reactions (Oztoprak and Pisirici, 2011). Higher CEC and exchangeable cations (except Ca) among the mineral samples are due to salinity characteristics (Sastre et al., 2007) and higher heavy metal sorption due to negative charge of clay fraction (Chalermyanont et al., 2009). Marine clay has highest $\mathrm{pH}$ values ranging from 6.95-8.36, in alkaline region due to calcareous content for this soil. According to (Sastre et al., 2007; Lukman et al., 2013), alkaline pH promotes heavy metal precipitation and adsorption onto clay surfaces. Organic matter in soils also plays an importance role in the adsorption of heavy metal ions even in soils and for this study, marine clay has the highest range of organic matter.

From Table 3 and Langmuir isotherms model, the selectivity sequence for $\mathrm{KL}$ on $\mathrm{Ni}$ is $\mathrm{SBMC2}>\mathrm{SBMC1}>$ $\mathrm{PKMC}>\mathrm{BGR}>\mathrm{PMS}>\mathrm{KGR}>\mathrm{BBMS} 2>\mathrm{BBMS} 1$ while for $\mathrm{Zn}$, the selectivity sequence of $\mathrm{Kd}$ are $\mathrm{SBMC2}>$ $\mathrm{SBMC} 1>\mathrm{PKMC}>\mathrm{BBMS} 1>\mathrm{BBMS} 2>\mathrm{PMS}>\mathrm{BGR}>$ KGR. Marine clay shows high value of $\mathrm{Kd}$ due to high clay fraction. Small particle size, with high pH (e.g.,: $\mathrm{pH}$ for PKMC $=7.94-8.36)$ and high organic matter (e.g.,: PKMC $=4.35-5.14 \%$ ) can enhance heavy metals retention. Granite and meta-sediment residual soils have lowest $\mathrm{Kd}$ values and the lowest sorption capacity 
because they have high percentage of sand fraction. This behavior also related to low percentage of surface area and low in organic matter. According to Zuhairi et al. (2008), the relationship between soil properties and adsorption parameters exist in a group of soils with different characteristics.

Figure 1 and 2 shows the $\mathrm{pH}$ value of the final solution. Marine clay samples seem to have higher $\mathrm{pH}$ value (alkaline) compared to the initial solution. At high $\mathrm{pH}$ values (above point of zero change), surface of marine clay has higher negative charge which results in higher attraction of cations $(\mathrm{Ni}+$ and $\mathrm{Zn} 2+$ ). For granitic and meta-sediment residual soils, they became more acidic compared to initial solution. At low $\mathrm{pH}$ (below the point of zero change), the exchange sites on granite and meta-sediment particle become positive, the $\mathrm{Ni}+$ and $\mathrm{Zn} 2+$ cations compete with $\mathrm{H}+$ ions in the solution for actives sites and consequently lower adsorption (Hefne et al., 2010).

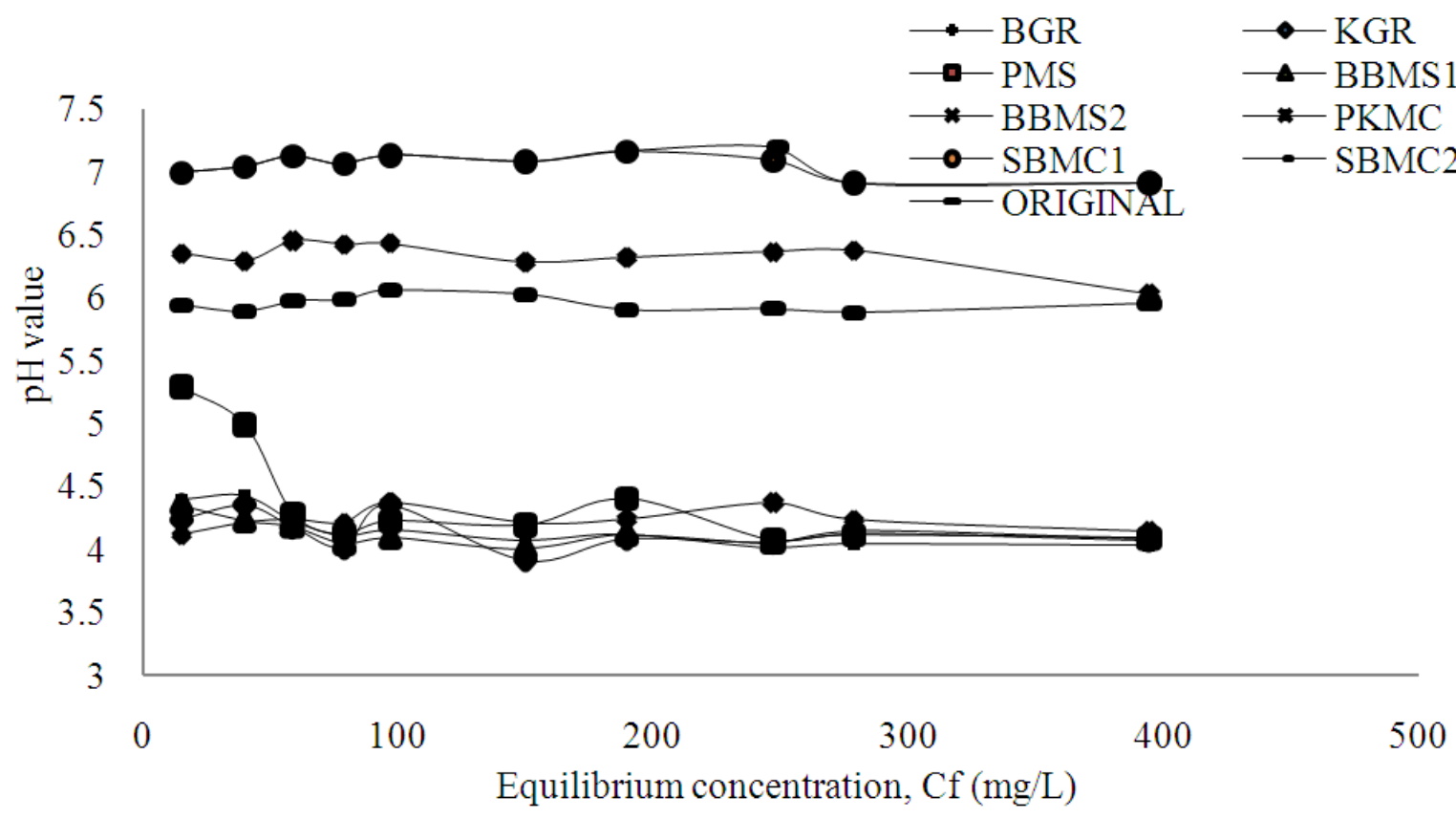

Fig. 1. $\mathrm{pH}$ value of final concentration of $\mathrm{Ni}$

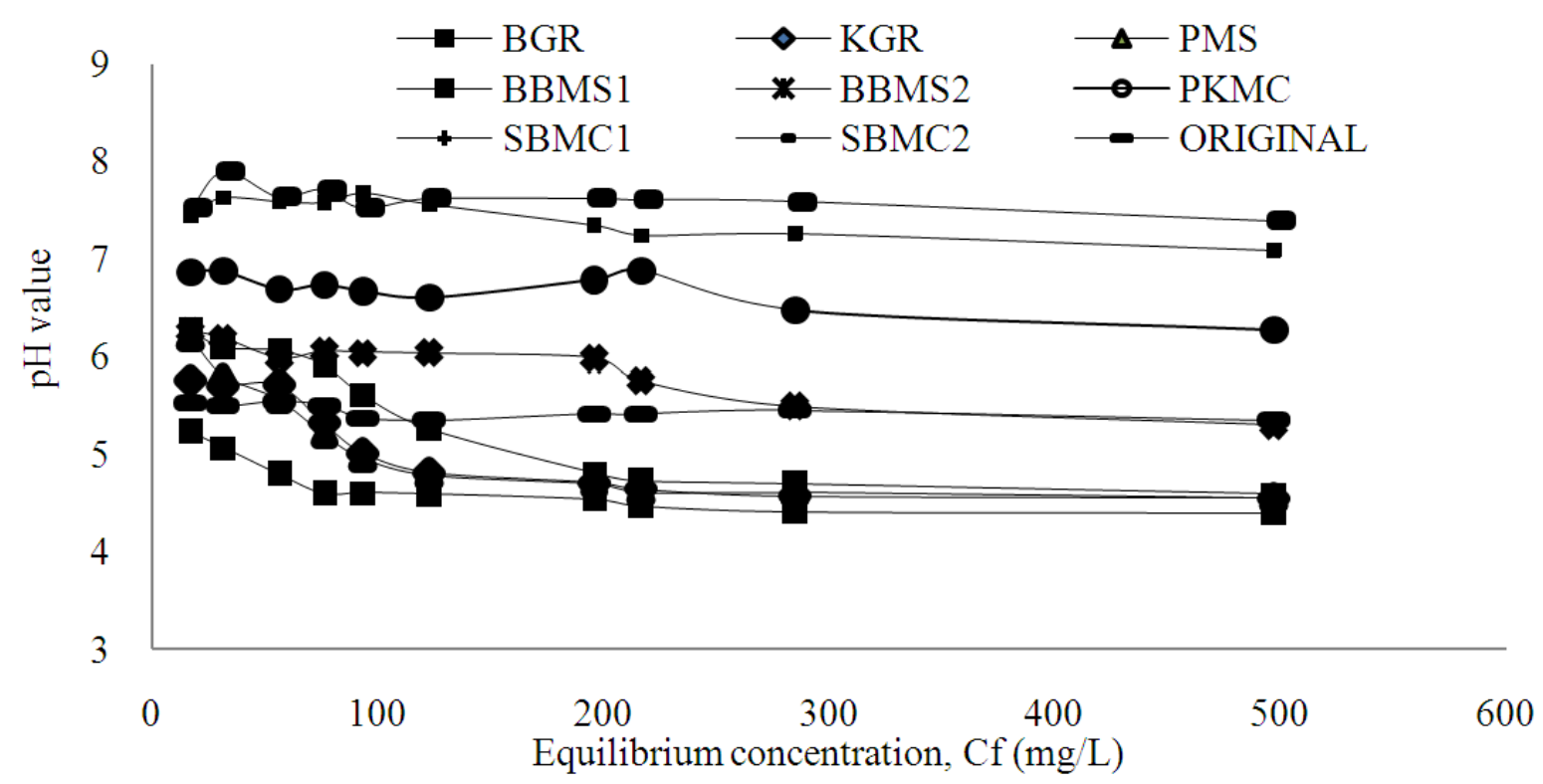

Fig. 2. $\mathrm{pH}$ value of final concentration of $\mathrm{Zn}$ 


\section{Conclusion}

Adsorption of $\mathrm{Ni}$ and $\mathrm{Zn}$ from aqueous state was studied under different concentrations. The Linear, Langmuir and Freundlich isotherm models explaining modest adsorbate-adsorbent interactions. The adsorbent, marine clay appeared to be the best natural adsorbent of $\mathrm{Ni}$ and $\mathrm{Zn}$ of metal concentration in solution. The rank for residual soil to be the best clay liner are marine clay> granite $>$ meta-sediment. Marine clay has suitable physical and chemical characteristics as we discussed above, due to higher adsorption capacity. Batch adsorption experiment was applied to study the adsorption characteristics of $\mathrm{Ni}$ and $\mathrm{Zn}$ onto residual soils. For $\mathrm{Ni}$, equilibrium data were well fitted to the Langmuir isotherm and Freundlich isotherm while for $\mathrm{Zn}$, equilibrium data were fitted to Linear equation. Marine clay performance was found to be better than the all other residual soils to adsorption of $\mathrm{Ni}$ and $\mathrm{Zn}$. Marine clay having the highest specific surface area (49.18-77.26\%), organic matter (4.35-6.41\%), cation exchange capacity (75.4-115.06 meq/100 g). The study concludes that marine clay is the best material for landfill clay liner.

\section{Acknowledgement}

This research was supported by Fundamental Research
Grant Scheme, Project No:
FRGS/1/2012/STWN06/UKM/02/2. Authors wish to thank
Geology Programme, Faculty of Science and Technology,
Universiti Kebangsaan Malaysia (UKM), Malaysia for their
assistance to conduct this study and writing this study.

\section{Funding Information}

Fundamental Research Grant Scheme, Project No: FRGS/1/2012/STWN06/UKM/02/2

\section{Author's Contributions}

Nur 'Aishah Zarime: Conducting the experimental work and drafting this paper,

W.Y. Wan Zuhairi: Is the main supervisor of the study and revise the article and

Sivarama Krishna: Who also revise this article.

\section{Ethics}

This article is original and contains unpublished materials. The corresponding author confirms that all of the other authors have read and approved the manuscript and no ethical issues involved.

\section{References}

Antoniadis, V., J.D. Mckinley and W.Y. Wan Zuhairi, 2007. Single-element and competitive metal mobility measured with column infiltration and batch tests. J. Environ. Q., 60: 53-60. DOI: 10.2134/jeq2006.0134
Babazadeh, H., A.H. Nazemi and M. Manshouri, 2011. Isotherm and kinetic studies on adsorption of $\mathrm{Pb}, \mathrm{Zn}$ and $\mathrm{Cu}$ by Kaolinite. Casp. J. Environ. Sci., 9: 243-255.

Chalermyanont, T., S. Arrykul and N. Charoenthaisong, 2009. Potential use of lateritic and marine clay soils as landfill liners to retain heavy metals. Waste Manage., 29: 117-27. DOI: 10.1016/j.wasman.2008.03.010

Galedar, M. and H. Younesi, 2013. Biosorption of ternary cadmium, nickel and cobalt ions from aqueous solution onto saccharomyces cerevisiae cells: Batch and column studies. Am. J. Biochem. Biotechnol., 9: 47-60. DOI: 10.3844/ajbbsp.2013.47.60

Hefne, J.A., W.K. Mekhemer, N.M. Alandis, O.A. Aldayel and T. Alajyan, 2010. Removal of silver (I) from Aqueous solutions by natural bentonite. JKAU: Sci., 22: 155-176.

Huang, B., Z. Li, J. Huang, L. Guo and X. Nie et al., 2014. Adsorption characteristics of $\mathrm{Cu}$ and $\mathrm{Zn}$ onto various size fractions of aggregates from red paddy soil. J. Hazardous Materials, 264: 176-183. DOI: 10.1016/j.jhazmat.2013.10.074

Komy, Z.R., A.M. Shaker, S.E.M. Heggy and M.E. ElSayed, 2013. Kinetic study for copper adsorption onto soil minerals in the absence and presence of humic acid. Chemosphere. DOI: 10.1016/j.chemosphere.2013.10.048

Li, Y., Q. Yue and B. Gao, 2010. Adsorption kinetics and desorption of $\mathrm{Cu}$ (II) and $\mathrm{Zn}$ (II) from aqueous solution onto humic acid. J. Hazardous Materials, 178: 455-461. DOI: 10.1016/j.jhazmat.2010.01.103

Oztoprak, S. and B. Pisirici, 2011. Effects of micro structure changes on the macro behaviour of Istanbul (Turkey) clays exposed to landfill leachate. Eng. Geol., 121: 110-122. DOI: 10.1016/j.enggeo.2011.05.005

Parida, K., K.G. Mishra and S.K. Dash, 2012. Adsorption of toxic metal ion $\mathrm{Cr}(\mathrm{VI})$ from aqueous state by TiO2-MCM-41: Equilibrium and kinetic studies. J. Hazardous Materials, 241-242: 395-403. DOI: 10.1016/j.jhazmat.2012.09.052

Ruffino, B. and M. Zanetti, 2009. Adsorption study of several hydrophobic organic contaminants on an aquifer material. Am. J. Environ. Sci., 5: 508-516. DOI: 10.3844/ajessp.2009.508.516

Lukman, S., M.H. Essa, D.M. Nuhu, A. Bukhari and C. Basheer, 2013. Adsorption and desorption of heavy metalsonto natureal clay material: Influence of initial pH. J. Environ. Sci. Technol., 6: 1-15. DOI: 10.3923/jest.2013.1.15

Sabahi, E.A., S.A. Rahim, W.Y.W. Zuhairi, A.N. Fadhl and F. Alshaeb, 2009. The characteristics of leachate and groundwater pollution at municipal solid waste landfill of Ibb city, Yemen. Am. J. Environ. Sci., 5: 230-240. DOI: 10.3844/ajessp.2009.256.266 
Sastre, J., G. Rauret and M. Vidal, 2007. Sorptiondesorption tests to assess the risk derived from metal contamination in mineral and organic soils. Environ. Int., 33: 246-56. DOI: 10.1016/j.envint.2006.09.017

Sivarama Krishna, L., M.C.S. Reddy and A. Varada Reddy, 2012. The use of an agricultural waste material, Jujuba seeds for the removal of anionic dye (Congo Red) from aqueous medium. J. Hazardous Material, 203-204: 118-127. DOI: 10.1016/j.jhazmat.2011.11.083

Taha, M.R., W.Y.W. Zuhairi, A.R. Samsudin and J. Yaacob, 2011. Groundwater quality at two landfill sites in Selangor, Malaysia. Bull. Geol. Society Malaysia, 57: 13-18. DOI: 10.7186/bgsm2011003

Tang, H., W. Zhou and L. Zhang, 2012. Adsorption isotherms and kinetics studies of malachite green on chitin hydrogels. J. Hazardous Materials, 209-210: 218-25. DOI: 10.1016/j.jhazmat.2012.01.010

Zuhairi, W.Y. and A.R. Samsudin, 2007. Sorption parameters of $\mathrm{Pb}$ and $\mathrm{Cu}$ on natural clay soils from Selangor, Malaysia. Sains Malays., 36: 149-157.
Zuhairi, W.Y., A.R. Samsudin and T.B. Kong, 2008. The sorption distribution coefficient of lead and copper on the selected soil samples from Selangor. Bull. Geol. Society Malaysia, 54: 21-25. DOI: 10.7186/bgsm2008004

Wang, S. and Z. Nan, 2009. Copper sorption behavior of selected soils of the oasis in the middle reaches of Heihe River Basin, China. Soil Sediment Contam., 18: 74-86. DOI: $10.1080 / 15320380802545415$

Zulfahmi, A.R., H. Umar and A. Noorulakma, 2011. Engineering geological properties of oilcontaminated granitic and metasedimentary soils. Sains Malaysiana, 40: 293-300. DOI: 10.3923/ajaps.2010.237.249

Liew, C.Y. and W.Y.W. Zuhairi, 2003. Application of residual soils as low-cost adsorbents for heavy metals.

Rosli, R., A.T.A. Karim, A.A.A. Latiff and M.R. Taha, 2008. Adsorption properties of as, $\mathrm{Pb}$ and $\mathrm{Cd}$ in soft soil and meta sedimentary residual soil. Proceedings of the Engineering Postgraduate Conference, (EPC' 08), pp: 1-9. 